\title{
Un mural parisino como ilustración de la patrimonialización polimórfica del exilio republicano
}

\author{
Fabien Van Geert | Université Sorbonne Nouvelle \\ URL de la contribución <www.iaph.es/revistaph/index.php/revistaph/article/view/5042>
}

Durante un paseo parisino en el 2020, nos sorprendió descubrir un mural titulado La Nueve de la 2e DB, ubicado en el número 20 de la calle Esquirol. Inaugurado el 24 de agosto de 2019 en el marco de la celebración del 75 aniversario de la Liberación de París y el 80 aniversario de "la retirada" (más bien conocida en España como exilio republicano), este mural de 17 metros de altura, realizado por la Association du 24 août 1944, representa el papel jugado por la columna Dronne de la 2e DB del General Leclerc en la Liberación de París, insistiendo en que esta última estaba compuesta en su mayoría por republicanos españoles que luchaban por el advenimiento de la república social y la erradicación del fascismo. Familiarizado con la historia de la Segunda Guerra Mundial, pero también de la Guerra Civil española después de vivir casi diez años en Barcelona, este hecho nos era desconocido. Y con razón. La presencia de extranjeros en las Fuerzas Francesas Libres sólo fue recordado a partir de 2004, tras la celebración del 60 aniversario de la Liberación de París que les rindió homenaje por primera vez. Al insistir sobre este hecho, esta conmemoración abrió una nueva página en la patrimonialización de este episodio histórico que hasta entonces se había forjado en el relato gaullista según el cual París había sido "liberada por sí misma, liberada por su pueblo", como afirmó el general durante su famoso discurso del 25 de agosto de 1944.

Mirando detenidamente este mural, un detalle nos sorprendió. Según los logotipos representados bajo este último, parecía que había sido financiado por los gobiernos francés y español, el Ayuntamiento de París, una oficina de vivienda pública (Paris Habitat), pero también sindicatos y muchas asociaciones, tanto españolas como francesas, que trabajan sobre la memoria del exilio republicano pero también en la promoción de los ideales republicanos, sindicalistas (la CGT y la CNT) y anarquistas (Fédération Anarchiste). Todas estas entidades habían contribuido a la realización de este mural a través de una suscripción lanzada por la asociación. ¿Cómo explicar este hecho, a pesar de sus grandes diferencias políticas? Examinar la construcción de la memoria del exilio republicano, en Francia y en España, nos permite comprender algunas de las razones.

Como señala Arrieta (2016), el proceso de creación de la memoria constituye un campo de negociación, incluso de luchas, entre distintos agentes, actores e instituciones. Esta creación evoluciona constantemente con el tiempo, pero también según los lugares de producción de esta memoria, así como con los intereses y visiones de sus múltiples actores. Analizando las lógicas de patrimonialización del exilio republicano, intrínsecamente transnacional por el carácter transfronterizo de este episodio, podemos definir diferentes relatos conformados a partir los años 1980-1990, tras su "redescubrimiento" a ambos lados de los Pirineos. Constitutiva de la historia de la inmigración en Francia, y de la memoria histórica en España, esta patrimonialización se articula entre una memoria política -colectiva- y una memoria cultural -oficial- (Assmann 2006), pero también entre diferentes memorias construidas tanto a escala local, nacional y europea. Es posible definir pues al menos cuatro discursos dentro de esta patrimonialización que muchas veces conviven en las acciones realizadas por las asociaciones y en los relatos de los espacios patrimoniales creados por los poderes públicos desde entonces.

Dicha patrimonialización se compone ante todo de una perspectiva militante que insiste en el carácter político 


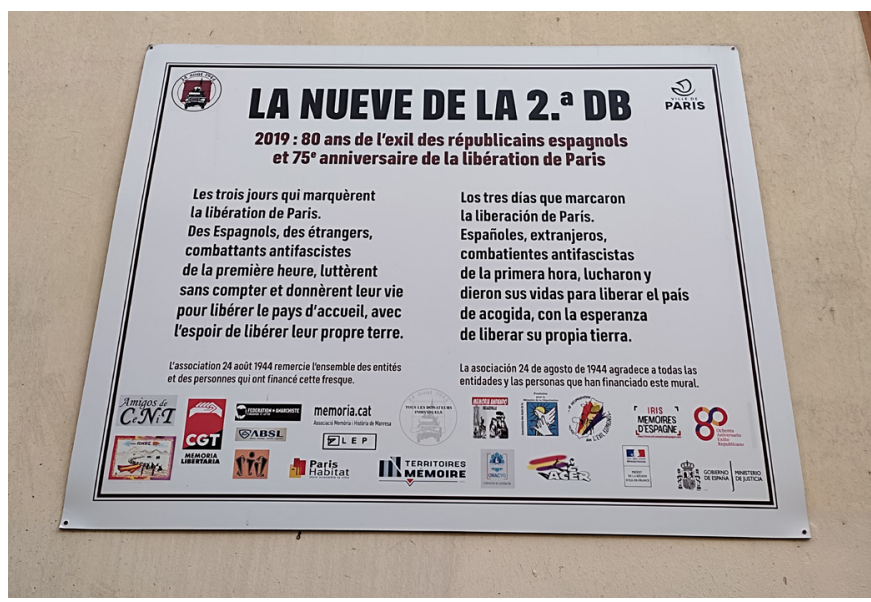

Benefactores del mural La Nueve de la 2e DB en París | foto Fabien Van Geert, 2021

del exilio, como afirman los descendientes de los republicanos en Francia o los simpatizantes del modelo republicano y de una mayor descentralización del Estado en España. El drama humanitario que supone este episodio se recalca, también, frente a la magnitud de este desplazamiento de población que tuvo lugar en pleno invierno y que no deja de recordar a las crisis migratorias contemporáneas o a los desplazamientos forzados de poblaciones civiles, como se indica en muchos espacios patrimoniales. Además, el aspecto vergonzoso de esta historia es recordado muchas veces insistiendo en la decisión del gobierno francés de internar a parte de estas personas en campos de concentración, incumpliendo con su credo de encarnar la "patria de los derechos humanos". En varias comunidades autónomas este exilio se presenta también como un patrimonio difícil de la España contemporánea, vinculando este episodio a la Guerra Civil, la dictadura franquista y a las dificultades actuales de salir de la "cultura de la transición". Finalmente, las consecuencias del exilio suelen ser visibles en este proceso de patrimonialización, al insistir, a ambos lados de la frontera, en la contribución de estas personas a la vida social, cultural y política de sus territorios de acogida, donde buena parte de ellas se asentaron.

Articulando estos distintos registros, la patrimonialización del exilio republicano es pues polimórfica. Al reunir, entre otros, a anarquistas, nacionalistas catalanes, sindicatos, activistas de la memoria histórica, el Ayuntamiento socialista parisino (gobernado por una descendiente de republicanos españoles) y gobiernos nacionales liberales, la financiación del fresco parisino atestigua esta particularidad. Si bien hay pocos puntos en común entre estas distintas entidades, todas demuestran un interés en uno $u$ otro de los relatos presentes en la patrimonialización del exilio republicano. Pero sobre todo, más allá del carácter democratizador de esta financiación participativa, el hecho de haber recurrido a dicha práctica (por falta de apoyo financiero) ilustra también la dificultad de los poderes públicos por asumir plenamente la memoria de este episodio que sigue haciendo eco a muchas cuestiones políticas e identitarias contemporáneas, a ambos lados de los Pirineos.

\section{BIBLIOGRAFÍA}

- Arrieta Urtizberea, I. (2016) Recordar y olvidar: emprendedores y lugares de memoria. En: Arrieta Urtizberea, I. (ed.) Lugares de memoria traumática. Bilbao: Editorial de la Universidad del País Vasco

- Assmann, A. (2006) Memory Individual and Collective. En: Goodin, R.E. y Tilly, C. (ed.) The Oxford Handbook of Contextual Political Analysis. Oxford: Oxford University Press 